\title{
Enucleation of Odontogenic Cyst with Bone Graft
}

\author{
Enucleación de Quiste Odontogénico con Injerto Óseo
}

\author{
Isabella Medeiros Garcia'; Fabio Nakao Arashiro²; Ellen Cristina Gaetti Jardim² \& Júlio César Leite da Silva²
}

GARCIA, I. M.; ARASHIRO, F. N.; JARDIM, E. C. G. \& SILVA, J. C. L. Enucleation of odontogenic cyst with bone graft. Int. J. Odontostomatol 13(4):433-436, 2019.

ABSTRACT: Periapical cyst originates from an inflammatory reaction in the body that occurs due to a long-term endodontic aggression. It is more prevalent in caucasian male, during the third decade of life, in the anterior portion of the maxilla. They are commonly radiographic findings, due to their asymptomatic aspect. This study reports a Periapical Cyst in the portion corresponding to teeth 21,22 and 23 , which was treated by enucleation of the cyst, apicoectomy and retrograde root filling with Mineral trioxide aggregate (M.T.A) of teeth 21 and 22, filling of the cyst cavity with xenogeneic bone graft GenOx and a collagen membrane Gen-Derm. Observations after three months show good and rapid bone regeneration, periodontal and periapical health of the teeth involved.

KEY WORDS: odontogenic cyst, bone graft, periapical cyst.

\section{INTRODUCTION}

Cyst odontogenic AND A pathological cavity surrounded FOR epithelium containing indoors your liquid or semisolid material. Benign lesion, Men Prevalence IN, Caucasian, during the 3rd decade life. How does source a response immuno-inflammatory periodontal cells for the long-term aggression caused for bacterial endotoxin and cytokine endodontic origin (Valois \& Costa-Júnior, 2005).

Radiographs routinely identify the cyst due to the absence of symptoms in most cases. In large cysts extension, observe swelling, asymmetry, fistula, mobility and dental displacement (Vasconcelos et al., 2012). Prevalent in previous jaw region (Araújo et al., 2013), are presented radiographically as radiolucent lesion, unilocular, ovoid or circular shape bounded well radiolucent in size halo and varies in each case (Pereira, 2013).

Treatment to odontogenic cyst and a topic much discussed in the literature. As Treatment Methods: conservative endodontic treatment, enucleation, marsupialization, decompression and extraction. Most cases presents interaction between OS treatments. The choice devel therapy Take into account the age and circumstances of the patient, location of the injury
SIZE and structures Involvement Anatomical so cause possible minor damage at the same.

This report presents the Treatment of periapical odontogenic cyst jaw in the area of elements 21, 22 and 23, with enucleation, apicoectomy and retrofilling to 21:22 with MTA, filling the cavity with bone graft Gen-Ox and covered with collagen membrane Gen-Derm. The therapy was developed because of the physical and psychological conditions of the patient, not even being the developer and holder of rheumatic disease with limited deft movements. In order to assess the outcome and characteristics acquired with the literature of different treatments.

\section{CASE REPORT}

Patient, male, 61, leucoderma. In anamnesis Chronic rheumatic disease with limited right hand drive. Without symptoms and painful complaints in the maxilla. If the clinical examination noted slight swelling in the buccal bone plate in the region of the elements 21,22 and 23 and palate region correspondent.

\footnotetext{
${ }^{1}$ Graduate in Dentistry at the Federal University of Mato Grosso do Sul, Brazil.

${ }^{2}$ Dentistry at the Federal University of Mato Grosso do Sul, Campo Grande, MS, Brazil.
} 
In the panoramic radiography observed if radiolucent lesion, well defined unilocular and well defined in the root tips of the elements 21,22 with endodontic treatments carried out previously. In tomography injury showed $13.79 \mathrm{~mm}$ high and 10.92 $\mathrm{mm}$ in the vestibule-palatal direction with buccal bone plate breaking. Laboratory tests showed no comorbidities.

In preoperative, one hour prior to surgery, were given two pills of dexamethasone $4 \mathrm{mg}$ and four pills of amoxicillin $500 \mathrm{mg}$. Regional anesthesia for lock, infiltrative terminal and subperiostal on the palate with articaine 4\% with epinephrine 1: 100,000.

Held retail Novak-Peter, with relaxing incisions in mesial and distal 21 to 23. Detachment mucoperiostal retail and later ostectomies with drill 702 and assisted irrigation saline. Cystic enucleation and curettage of the store (Fig. 1). The capsule was sent to the pathology laboratory for histopathological analysis in $10 \%$ formalin, with conclusive report of odontogenic cyst. The endodontic surgery began with

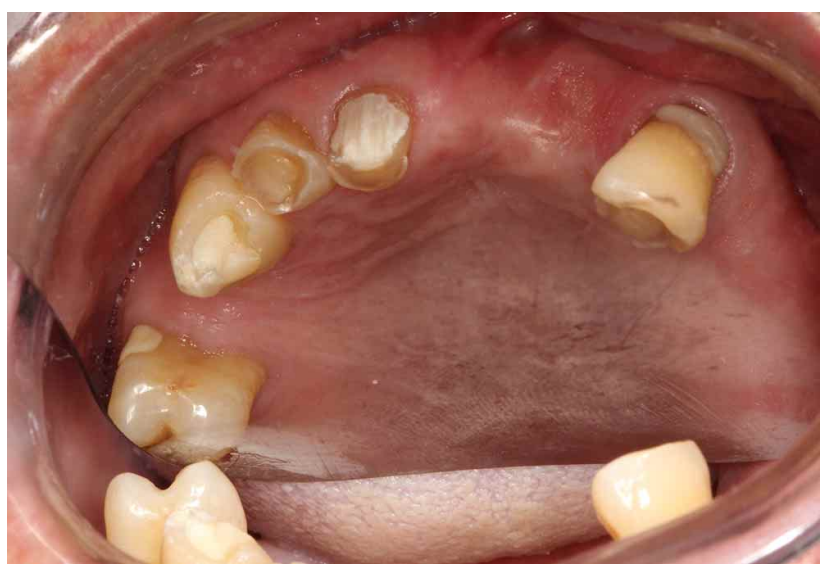

Fig. 1. Initial clinic.

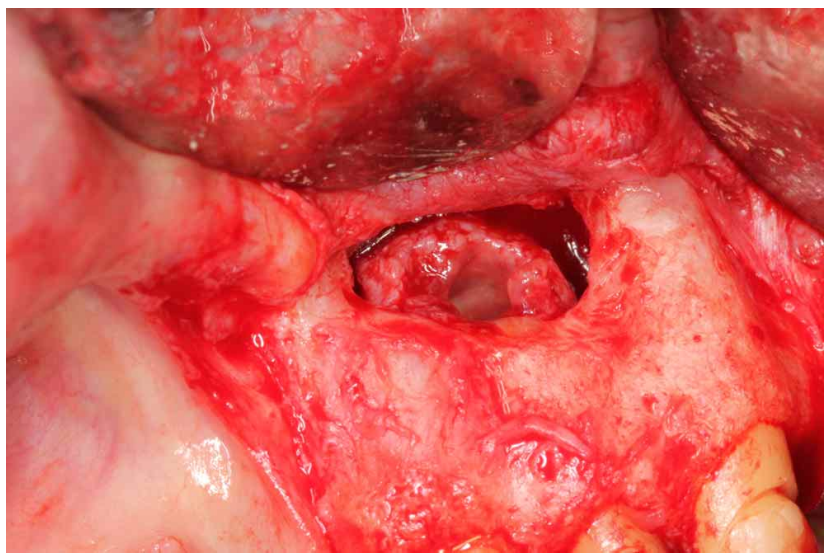

Fig. 2. Cystic enucleation and curettage of the store. scraping of the roots of $21: 22$ and cleaning of interroot spaces. Later apicoectomy removing $3 \mathrm{~mm}$ apical. It was held retrofillingon element 23 , as the apical third of this tooth was not involved in the injury. The retropreparations were performed with $\mathrm{P} 1 \mathrm{M}$ tip ultrasound device and retrofilling with endodontic cement MTA (Figs. 2 to 4 ).

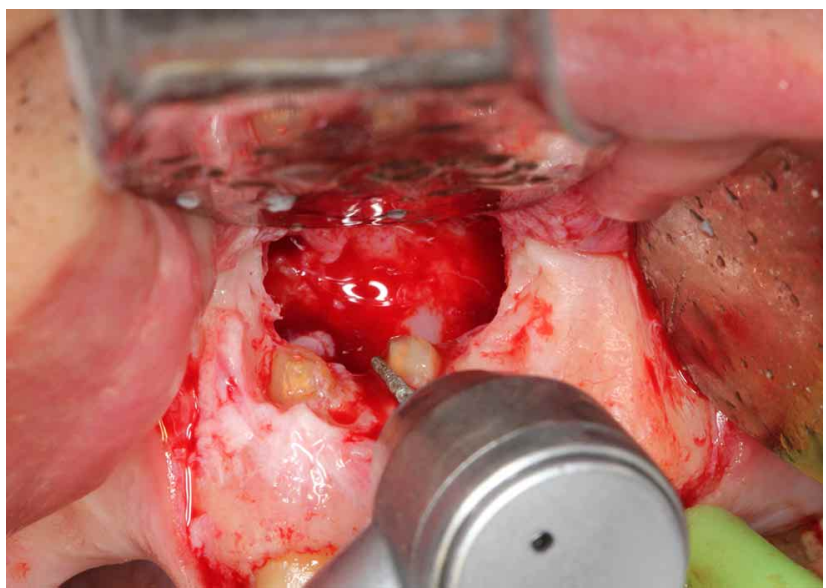

Fig. 3. Endodontic surgery began with scraping of the roots and retro-preparations.

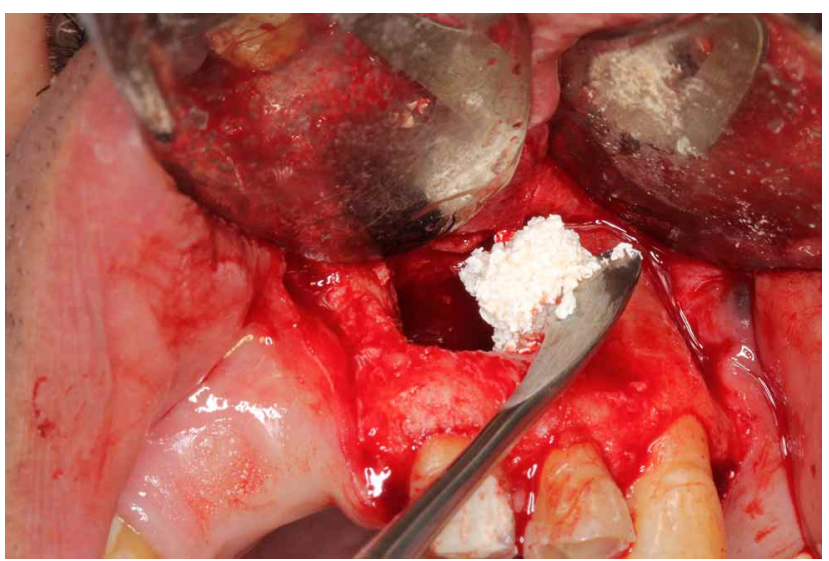

Fig. 4. Gen-Ox.

Was part of Gen-Ox in the cavity with blood promoted in cystic store. The Gen-Derm membrane was cut in shape and size compatible covering the surgical cavity. Repositioning and suturing the flap with nylon thread 4-0 (Figs. 5 and 6).

Post-surgery with medical therapy Dipyrone Sodium $500 \mathrm{mg}$ of 6 in 6 hours for 2 days and lbuprofen $600 \mathrm{mg}$ every 12 hours for 3 days and post-surgical guidance. After one week was removed sutures with excellent cleaning and scarring with no signs and symptoms of inflammation or infection. 
After three months, tomography was performed and radiography control observing good bone regeneration, fill the cavity with bone grafting, periodontal health of teeth, sealed apical thirds and no infectious relapse signal. The patient remains in followup.

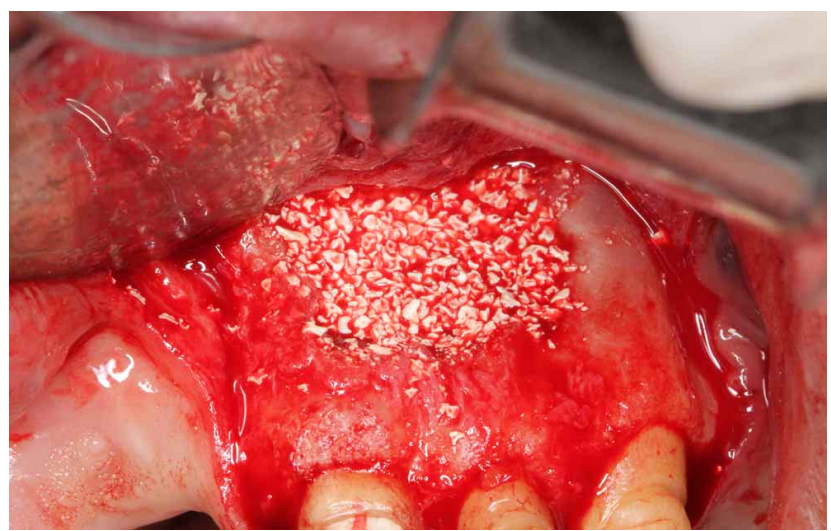

Fig. 5. Size compatible covering the surgical cavity.

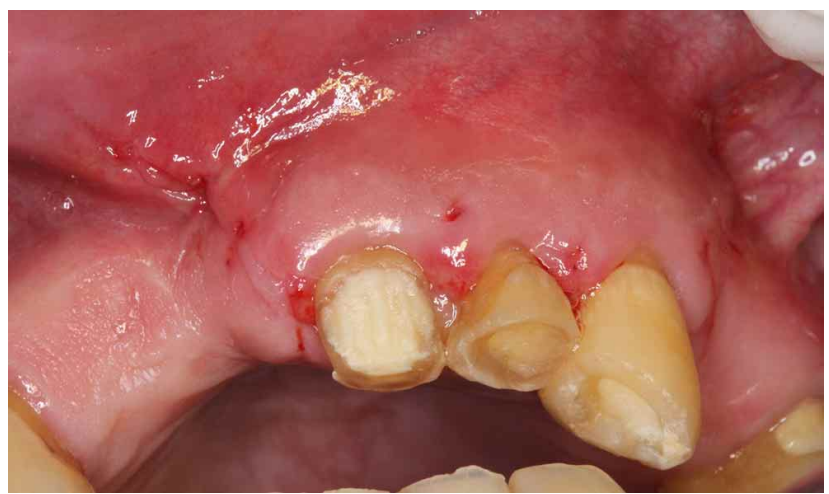

Fig. 6. Repositioning and suturing the flap with nylon thread 4-0.

\section{DISCUSSION}

The periapical cyst odontogenic also named as apical or radicular cyst is a true cyst (Pereira), the most common pathology and the incident gnathic bones (Martins, 2012). Histologically presented as cystic squamous epithelium stratified non-keratinized, with dense fibrous connective tissue capsule, containing inside liquid material or semi-solid and squamous cells (Pereira).

Your treatment should be performed briefly at diagnosis, although it is slow-growing, is an osteolytic lesion able to expand due to great pressure inside (Pereira), destroying the surrounding bone. This explains the prevalence in the maxilla, it is a spongy promoting greater expandability of the injury. Recurrence capacity is also greater in the maxilla, as the close relationship of the lesion with the epithelium of the maxillary sinus and nasal cavity, making the separation of the cystic capsule with no pathological epithelium (Araújo et al.).

Enucleation of therapeutic, retrofilling and bone graft was determined because of the difficulty of hand movements and patient behavior. The treatment by decompression require irrigation of the surgical cavity with physiological saline three times daily and accurate oral hygiene. In the absence or difficulty of them, the infection was a complication possibly observed.

Decompression promotes discomfort with the use and daily care of the drains. In addition to pain, difficulty in cleaning, time consuming and result commitment of local anatomical structures (Pereira). In this case, the drain on the vestibular region locate the elements 21 and 22 working against the aesthetic and well being of the patient. Cystic enucleation is recommended for minor injuries and where there is no proximity to noble anatomical structures. This technique promotes complete removal of the lesion, preventing future recurrences (Pereira), in addition to achieving the histopathological study altogether. It is a definite need for further treatment without surgical intervention.

The paraendodontic surgery is indicated when there is failure of root canal treatment already done and in cases of persistent periapical lesions with cystic characteristics (Lodi et al., 2008). The non-surgical treatment for endodontic cyst require several months to follow, the switching delay of wound dressing to reduce injury and promote bone formation (Valois \& Costa-Júnior), this time feasible by the patient.

The sealing of root canals provided by endodontic surgery, prevents micro-organisms and their endotoxins acometam the periapical tissues avoiding the recurrence of the lesion (Lodi et al.). The MTA is the material of choice in retro-obrurações because their sealing properties, biocompatibility and sealing ; not being cytotoxic to tissue adjacent promotes bone regeneration (Teruya, 2007).

The injured bone tissue has regenerative capacity and repair, however, depending on the defect size, does not regenerate completely. The chosen biomaterial must be biocompatible, osteoinductive, osteoconductive, osteogenic, easily obtained, economic, among others. However no known biomaterial has all the requisite characteristics (Fardin et al., 2010). 
The autograft adapts more to these characteristics, but the disadvantages such as the need for donor area, potential absorption and difficulty in adapting the receiving area, prevents that choice just in case. The xenogeneic graft was chosen because it reduces postoperative morbidity requiring no other surgical site (Fardin et al.).

Gen-Ox is an osteoconductive inorganic matrix of cancellous bovine cancellous bone structure and features similar to human bone. Your component is the natural hydroxyapatite of high purity. Used to cover bone defects, for anchoring implants, periodontal bone lesions and periradicular surgery.

Your bone healing time is between 7-9 months as has slow absorption. For be osteoconductive, GenOx Inorganic allows new bone apposition on its surface , requiring the presence of pre -existing bone tissue as a source of osteoprogenitor cells (Fardin et al.).

The collagen membrane is essential for tissue regeneration guide. Gen-Derm is a resorbable membrane of bovine cortical bone. Used as a natural biological barrier and osteoprotetora, preventing intussusception not osteogenic cells in areas of bone grafting. It is reabsorbed after 45 days and does not require another surgical procedure for removal.

Three months after the surgery in tomography and radiography panoramic control, obser if entire cavity filled and bone regeneration, periodontal tissues of health and no sign and symptom recurrence.

\section{CONCLUSION}

The enucleation retrofilling and promotes bone graft in one session, total removal of the lesion and causes to fill the cavity. Observed quick result with bone formation, sealing the apex, periodontal health of teeth and no sign or symptom recurrence.

GARCIA, I. M.; ARASHIRO, F. N.; JARDIM, E. C. G. \& SILVA, J. C. L. Enucleación de Quiste odontogénico con Injerto oseo. Int. J. Odontostomatol 13(4):433-436, 2019.

RESUMEN: El quiste periapical se origina de una reacción inflamatoria que ocurre debido a una agresión endodóntica a largo plazo. Es más frecuente en el varón caucásico, durante la tercera década de la vida, en la por- ción anterior del maxilar. Son comúnmente hallazgos radiográficos, debido a su aspecto asintomático. En este estudio informamos acerca de un quiste periapical, en la porción correspondiente a los dientes 21,22 y 23 , que se trató mediante enucleación, apicectomía y relleno de raíz retrógrada con agregado de trióxido mineral (MTA) de los dientes 21 y 22, relleno de la cavidad del quiste con injerto óseo xenogénico Gen-Ox y una membrana de colágeno GenDerm. Las observaciones después de tres meses mostraron una buena y rápida regeneración ósea, con conservación de la salud periodontal y periapical de los dientes involucrados.

PALABRAS CLAVE: quiste odontogénico, injerto óseo, quiste periapical.

\section{REFERENCES}

Araújo, F. A. C.; Landim, F. S.; Rocha, N. S.; Caubi, A. F. \& Morais, H. H. A. Tratamento de extenso cisto inflamatório em maxila relato de caso. Rev. Cir. Traumatol. Buco-Maxilo-Fac., 13(2):81 6, 2013.

Fardin, A. C.; Jardim, E. C. G; Pereira, F. C; Guskuma, M. H.; Aranega, A. M. \& Garcia Júnior, I. R. Enxerto ósseo em odontologia: revisão de literatura. Innov. Implant J., 5(3):48-52, 2010.

Lodi, L. M.; Poleto, S.; Soares, R. G.; Irala, L. E. D.; Salles, A. A. \& Limongi, O. Cirurgia paraendodôntica: relato de caso clínico. Rev. Sul-Bras. Odontol., 5(2):69-74, 2008.

Martins, T. H. Cistos e Tumores Odontogênicos. Estudo Retrospectivo. Londrina, Departamento de Medicina Oral e Odontologia Infantil na UEL, 2012.

Pereira, R. C. Tratamento de Cisto Periapical de Grande Extensão. Relato de Dois Casos. Título de Especialista em Endodontia. Piracicaba, UNICAMP, 2013.

Teruya, L. I. Materiais Utilizados em Retrobturações em Cirurgias Parendodônticas. Título de Especialista em Endodontia. Santo André, Associação Paulista de Cirurgiões-Dentistas de Santo André, 2007

Valois, C. R. A. \& Costa-Júnior, E. D. Periapical cyst repair after nonsurgical endodontic therapy - case report. Braz. Dent. J., 16(3):254-8, 2005.

Vasconcelos, R. G.; Queiroz, L. M. G.; Alves Júnior, L. C.; Germano, A. R. \& Vasconcelos, M. G. Abordagem terapêutica em cisto radicular de grandes proporções - Relato de Caso. Rev. Bras. Ciênc. Saúde, 16(3):467-74, 2012.

Corresponding author:

Ellen Cristina Gaetti Jardim

Dentistry at the Federal University of Mato Grosso do Sul

Campo Grande, MS

BRAZIL

Email:ellengaetti@gmail.com

Received: 04-06-2019

Accepted: 05-07-2019 